\title{
Zakres i treść ustawy budżetowej jako zagadnienie konstytucyjne (głos w dyskusji)
}

Przedmiotem niniejszego opracowania jest przedstawienie niektórych aspektów prawno-ustrojowych dotyczących zakresu i kształtu ustawy budżetowej, a w szczególności rozważenie, czy współczesny budżet stosowany w Polsce (ujęty w ustawie budżetowej) odpowiada wymogom konstytucyjnym.

W ustroju demokratyczno-parlamentarnym prawo zatwierdzania budżetu przez parlament zapewnia mu wpływ na politykę rządu i daje podstawę kontroli. Budżet musi być uchwalany (zatwierdzany) przez parlament, jest aktem władzy przedstawicielskiej. Akt finansowy, przedstawiający dochody i wydatki państwa niezatwierdzany przez parlament - nie jest budżetem.

Konstytucja powinna dawać wyraźne wskazówki do ustaw zwykłych tworzących prawo budżetowe danego państwa. Ustawa o finansach publicznych $\mathrm{i}$ inne ustawy finansowe muszą - w nawiązaniu do wymogów konstytucyjnych kształtować instytucje prawne ustawy budżetowej, deficytu budżetowego, zakresu i układu budżetu, przedsiębiorstw publicznych, finansowania ubezpieczeń społecznych. Konstytucja musi też określać podstawowe właściwości corocznej ustawy budżetowej.

Konstytucja Rzeczypospolitej Polskiej z 17 marca 1921 r. stanowiła w art. 4, że ustawa państwowa ustala corocznie budżet państwa na następny rok budżetowy. Art. 10 Konstytucji marcowej określa, że wnioski i projekty ustaw, pociągające za sobą wydatki ze Skarbu Państwa, muszą podawać sposób ich zużycia i pokrycia.

Ustawa konstytucyjna z 23 kwietnia 1935 r. stanowiła w art. 58, że ustawa ustala corocznie budżet państwa oraz że państwo nie może pozostawać bez budżetu (art. 60). Konstytucja kwietniowa postanawia, że rząd nie może czynić wydatków bez upoważnienia ustawowego, chyba że zachodzi konieczność państwowa - w tym przypadku rząd, na podstawie uchwały Rady Ministrów, dokona niezbędnego wydatku, przesyłając do Sejmu w terminie siedmiodniowym od powzięcia uchwały projekt ustawy o przyznaniu kredytów dodatkowych.

* Prof. zw. dr hab. Andrzej Borodo - Katedra Prawa Budżetowego i Finansów Samorządu Terytorialnego, Wydział Prawa i Administracji, Uniwersytet Mikołaja Kopernika w Toruniu. 
Współczesna Konstytucja RP z 2 kwietnia 1997 r. stanowi w art. 219 ust. 1, że Sejm uchwala budżet państwa na rok budżetowy w formie ustawy budżetowej. Nie określa treści i kształtu ustawy budżetowej ${ }^{1}$. Z przepisów Konstytucji z 1997 r. można wnioskować, że budżet państwa jest to akt prawny stanowiony przez Sejm w formie ustawy budżetowej, a jego przedmiotem są dochody i wydatki państwa ustalane na jeden rok. Sądzę, że obecne polskie ujęcia konstytucyjne są zbyt ogólnikowe i w niewystarczający sposób zakreślają wymogi dla ustawy budżetowej oraz ustawy o finansach publicznych.

Budżet państwowy powinien być skonstruowany, uchwalany i wykonywany zgodnie z zasadami budżetowymi. Zasady budżetowe powinny być stosowane przez rządy i parlamenty, muszą być elementem porządku prawnego w państwie, składnikiem obowiązującego prawa konstytucyjnego i finansowego. Budżet niezgodny z zasadami budżetowymi jest wyrazem nieprawidłowości rządzenia. Problematyka pojęcia, znaczenia i funkcji zasad budżetowych należy do nauki finansów publicznych i prawa finansowego. Z rozwojem praktyki finansowej w Polsce zmienia się rola zasad budżetowych. Są one powiązane z praktycznymi funkcjami i zadaniami budżetu państwa w gospodarce rynkowej i w demokracji parlamentarnej opartej na walce i konkurencji sił politycznych. Zasady budżetowe muszą być więc badane na gruncie współczesnej gospodarki rynkowej, pluralistycznej, bazującej na grze interesów; muszą być traktowane jako konstrukcje realnie kształtujące treści budżetowe. Jeżeli miały one zostać jedynie „fasadową dekoracją" i ,historycznym ozdobnikiem”, to byłoby to niekorzystne dla praktyki państwowej.

Analiz finansowych i prawnych wymagają wszystkie zasady budżetowe, m.in. zasada równowagi budżetowej i mechanizmy finansowania deficytu budżetowego, zasada zupełności budżetu (związana m.in. z problemem konsolidacji finansów publicznych w ramach budżetu państwa), zasada szczegółowości, jasności i jawności budżetu.

Zasada zupełności wymaga, aby budżet obejmował wszystkie dochody i wydatki państwa. Parlament, uchwalając budżet, powinien decydować o wszystkich dochodach i wydatkach państwowych, a nie tylko o niektórych. Budżet niezupełny stawia pod znakiem zapytania wartość planowanej lub osiągniętej równowagi budżetowej².

W praktyce i regulacjach prawnych współcześnie stosowanych w Polsce występuje problem zupełności budżetu państwa. Czy na gruncie obecnych ujęć konstytucyjnych z 1997 r. budżet ma być zupełny, czy ma obejmować wszystkie dochody i wydatki państwa, czy tylko niektóre? Czy deficyt budżetowy to wielkość wskazująca na brak pokrycia całości wydatków publicznych możliwymi do uzyskania wszystkimi dochodami państwa, czy jest to wielkość fragmentaryczna,

\footnotetext{
${ }^{1}$ C. Kosikowski, Finanse publiczne w świetle Konstytucji RP, Warszawa 2004, s. 81.

2 R. Rybarski, Nauka skarbowości, Warszawa 1935, s. 27.
} 
wyjęta z całości? Czy deficyt ustalany w ustawie budżetowej mówi o deficycie całego sektora publicznego?

Jeżeli Sejm współcześnie uchwala budżet państwa i zawarty w nim deficyt budżetu państwa (a nie deficyt sektora finansów publicznych), to stanowi o niedoborach w pewnej dziedzinie finansów, a nie o wielkości deficytu całości finansów publicznych. A jeżeli decyduje o części deficytu publicznego (a nie o całości), to czy jest to zgodne z Konstytucją RP? Sądzę, że nie.

Bez budżetu zupełnego, całościowego, deficyt budżetowy jest wielkością drugoplanową, fasadową. Konstytucja powinna zmusić rządy do budowania budżetu zupełnego i ukazywania rzeczywistego deficytu finansów państwa.

W okresie II RP zasada zupełności (powszechności) budżetu była rozpatrywana m.in. w aspekcie funkcjonowania przedsiębiorstw państwowych i ich budżetowego ujęcia. Przedsiębiorstwa te (także skomercjalizowane, mające osobowość prawną) były jednak traktowane jako podmioty państwa (a ich finanse jako finanse państwa). Dokonano wówczas podziału budżetu państwowego na budżet administracyjny i budżety przedsiębiorstw. Powiązania przedsiębiorstw z budżetem miały nieraz konstrukcję powiązania netto (wpłatami przedsiębiorstw do budżetu lub dopłatami ze skarbu do przedsiębiorstw), jednak plany finansowo-gospodarcze tych podmiotów były brutto ujęte w budżecie w ramach budżetowej grupy B - Przedsiębiorstwa. Dawało to ciałom ustawodawczym i opinii publicznej możliwość zorientowania się w kwestii pozycji gospodarki finansowej przedsiębiorstw należących do państwa.

Ponadto, w polskiej praktyce budżetowej okresu II RP pożyczki nie były traktowane jako dochody budżetowe, nie były więc na ogół wpisywane do budżetu. Wpływy z pożyczek i ich użycie (przeznaczenie) określano w odrębnej ustawie, nienależącej do budżetu. T. Grodyński stoi na stanowisku, że pożyczki to nie są dochody budżetowe, ale antycypacja przyszłych dochodów ${ }^{3}$. Uważano, że pożyczki państwowe (o ile w ogóle je stosować) powinny być kierowane na cele twórcze, inwestycyjne. Dochody z pożyczek nie były w zasadzie ujmowane w budżecie, natomiast spłata pożyczek (kapitału i odsetek) następowała z kredytów (wydatków) budżetowych ${ }^{4}$.

W RFN budżet federalny składa się z kilku części. Są to w szczególności budżety poszczególnych resortów, budżet ogólny (całościowy), ujęcia przeglądowe (objaśniające) poszczególnych dziedzin działalności ${ }^{5}$. Budżet ogólny zawiera m.in. plan finansowy określający finansowanie zadań w oparciu o dług publiczny. W planie tym ustalone są wpływy z kredytów zaciąganych na rynku finansowym i kwoty przeznaczone na spłaty długów.

${ }^{3}$ T. Grodyński, Zasady gospodarstwa budżetowego w Polsce na tle porównawczym, Kraków 1932, s. 49.

${ }^{4}$ I. Weinfeld, Skarbowość polska, Warszawa 1935, s. 118.

${ }^{5}$ E. Piduch, Das Staatshaushaltsrecht, [w:] V. Arnold, O.-E. Geske (red.), Öffentliche Finanzwirtschaft, München 1988, s. 138. 
Ustawa zasadnicza Republiki Federalnej Niemiec stanowi w art. 109, że związek i kraje związkowe wypełniają zobowiązania wynikające z traktatów unijnych dotyczące dyscypliny budżetowej i uwzględniają w swej gospodarce budżetowej wymagania ogólnej równowagi gospodarczej. Budżety tych władz powinny być równoważone w zasadzie bez udziału kredytów. Art. 115 Konstytucji niemieckiej stanowi, że zaciągnięcie przez władze federalne kredytu lub udzielenie poręczenia bądź gwarancji - które prowadzi do wydatków budżetowych w przyszłych okresach - wymaga upoważnienia ustawowego. Przepis ten wprowadza też zasadę, zgodnie z którą równowaga budżetowa jest zachowana, gdy wpływy budżetowe $\mathrm{z}$ tytułu kredytów przeznaczone na finansowanie deficytu budżetowego nie przekraczają 0,35\% nominalnego produktu krajowego brutto. Reguła 0,35 PKB jako granica finansowania deficytu ma jednak (przewidziane w art. 115) dodatkowe uwarunkowania i wyjątki. Poprzednia (nieobowiązująca już) wersja art. 115 Konstytucji RFN stanowiła, że wpływy z zaciągniętych kredytów rządowych nie powinny przekraczać kwoty przewidzianej w budżecie na cele inwestycyjne, a wyjątki od tej zasady dopuszczalne były w przypadku potrzeby zachowania ogólnej równowagi gospodarczej ${ }^{6}$.

Czy nieujmowanie współcześnie w polskiej ustawie budżetowej dochodów i wydatków Krajowego Funduszu Drogowego i innych funduszów prowadzonych i obsługiwanych przez Bank Gospodarstwa Krajowego jest zgodne z Konstytucją RP?

Zauważyć trzeba, że z przepisów ustawy z 27 października 1994 r. o autostradach płatnych oraz o Krajowym Funduszu Drogowym (t.j. Dz. U. z 2004 r. Nr 256, poz. 2571 ze zm.) wynika, że finansowanie zadań w zakresie dróg krajowych (zwłaszcza autostrad) jest realizowane ze środków Krajowego Funduszu Drogowego, które pochodzą z opłaty paliwowej (pobieranej od ilości wprowadzanych na rynek krajowy paliw silnikowych oraz gazu), przychodów z akcji i udziałów niektórych spółek należących do Skarbu Państwa, z opłat za przejazd autostradą, ze środków z tytułu kredytów i pożyczek zaciąganych na rzecz Funduszu przez Bank Gospodarstwa Krajowego, wpływów z obligacji emitowanych na rzecz Funduszu przez Bank Gospodarstwa Krajowego, dotacji z budżetu państwa, opłat i kar określonych w ustawie o drogach publicznych, innych dochodów. Krajowy Fundusz Drogowy nie jest jednak ujmowany w ustawie budżetowej. Także inne fundusze prowadzone przez Bank Gospodarstwa Krajowego (Fundusz Rozwoju Inwestycji Komunalnych, Fundusz Termomodernizacji i Remontów, Fundusz Kolejowy, Fundusz Żeglugi Śródlądowej, Fundusz Pożyczek i Kredytów Studenckich, Fundusz Strefowy) nie są objęte ustawą budżetową.

Powstaje też pytanie o konstytucyjne znaczenie kredytu publicznego (długu publicznego) jako źródła finansowania zadań publicznych. Ma to istotne znaczenie

${ }^{6}$ Por. R. F. Heller, Haushaltsgrundsätze für Bund, Länder und Gemeinden, Heidelberg 2010, s. $471 \mathrm{i} \mathrm{n.}$ 
teoretyczne i praktyczne. Można przyjąć, że wydatki budżetowe powinny być pokryte z danin i innych środków bezzwrotnych, a pożyczki i kredyty mają być kierowane tylko na cele rozwojowe. Gdyby przyjąć takie założenie, to finansowanie bieżących zadań państwa powinny pokrywać podatki i inne dochody bezzwrotne, a w dziedzinie celów inwestycyjnych, rozwojowych należy podjąć ich finansowanie z pożyczek, kredytów i obligacji skarbowych. Wydaje się, że stałe, konieczne zadania państwa nie powinny opierać się na finansowaniu pochodzącym z pożyczek, kredytów i obligacji.

Regulacji prawnych na temat szczegółowych celów, na które są przeznaczane wpływy z obligacji skarbowych nie ma. Mamy tylko bardzo ogólną zasadę, zgodnie z którą obligacje skarbowe są skierowane na finansowanie potrzeb pożyczkowych budżetu państwa.

Czy sprawę finansowania zadań państwowych (w tym zadań inwestycyjnych) należy pozostawić swobodnej decyzji polityków tworzących roczne budżety, czy można ją ująć w bardziej sztywne ramy konstytucyjne, wymuszające określone granice co do źródeł finansowania zadań bieżących i inwestycyjnych? Chodzi m.in. o wprowadzenie regulacji wiążących rozmiary wydatków inwestycyjnych budżetu z rozmiarami dochodów z majątku, podatków o charakterze inwestycyjnym oraz wielkością zaciąganych pożyczek. Wyraźne granice i źródła wydatków majątkowych (tzw. nadzwyczajnych) stosowało ustawodawstwo budżetowe w II RP.

Powstaje bowiem pytanie - o charakterze ustrojowym - związane z problemem: czy finansowanie bieżących zadań państwa w oparciu o pożyczki jest dopuszczalne z punktu widzenia podstawowych interesów państwowych? Jeżeli przyjąć, że jest dopuszczalne, to w jakich granicach i na jakich warunkach?

Brak ustrojowej koncepcji co do znaczenia pożyczek publicznych jest mankamentem obecnych regulacji polskich. Przepisy konstytucyjne dają władzy rządowej olbrzymie możliwości do prowadzenia w istocie dowolnej polityki wydatkowej, której nie ograniczają źródła dochodowe. Wpływy z danin nie stanowią bariery finansowania, w razie ich braku stosowane są wpływy ze sprzedaży obligacji. Konstytucyjne ograniczenie skali długu (60\% PKB), bez wskazania, na co wpływy oparte na zadłużeniu mogą być użyte, stanowi zbyt ogólną regulację.

Sądzę, że przyjęcie regulacji konstytucyjnych dotyczących m.in. źródeł finasowania wydatków inwestycyjnych państwa oraz przesłanek dotyczących stosowania deficytu jest sprawą istotną. Brak konstytucyjnego ujęcia sprawy źródeł finansowania zadań bieżących i inwestycyjnych państwa oraz deficytu publicznego daje zbyt dużą swobodę dla władzy rządowej w sprawach finansowania działalności państwa, zwłaszcza przy pomocy źródeł pożyczkowych. Konstytucja RP powinna regulować, czy i w jakim zakresie pożyczki mogą finansować działalność bieżącą (zwyczajną) państwa, czyli taką, która powinna być finansowana z podatków, składek i opłat. 